DOI: https://doi.org/10.31933/dijemss.v2i4 Received: $18^{\text {th }}$ Febuary 2021, Revised: $18^{\text {th }}$ March 2021, Publish: $18^{\text {th }}$ March 2021

\begin{tabular}{|c|c|c|}
\hline DINASTIS & $\begin{array}{l}\text { DIJEMSS } \\
\text { DINASTI INTERNATIONAL JOURNAL } \\
\text { OF EDUCATION MANAGEMENT AND } \\
\text { SOCIAL SCIENCE }\end{array}$ & $\begin{array}{r}\text { https://dinastipub.org/DIJEMSS } \\
\text { editor@dinastipub.org } \\
08117401455 \square\end{array}$ \\
\hline
\end{tabular}

\title{
THE ROLE OF ORGANIZATIONAL COMMITMENT AND ORGANIZATIONAL JUSTICE IN INFLUENCING TURNOVER INTENTION THROUGH JOB SATISFACTION AS ITS MEDIATES VARIABLE
}

\author{
Kurnia Magfuroh ${ }^{1}$, Anik Herminingsih ${ }^{2}$ \\ 1) Universitas Mercu Buana, Jakarta, Indonesia, kurniamagfuroh10@gmail.com \\ ${ }^{2)}$ Universitas Mercu Buana, Jakarta, Indonesia, anik_herminingsih@mercubuana.ac.id
}

\section{Corresponding Author: Kurnia Magfuroh}

\begin{abstract}
This research aims to investigate and analyze further relates to the affect which caused by organizational commitment and organizational justice to turnover intention through job satisfaction as its mediator on the employees of PT. Bank XYZ at Regional Office in Jakarta BSD. The criteria of research sample used was permanent employees. The sampling method done by proportional stratified random sampling with a total samples of 154 . The data collection technique used a questionnaire. Data analysis method used SEM-PLS. The results showed that the organizational commitment had a positive and significant impact on job satisfaction, but had a negative and significant impact on turnover intention. Organizational justice had a negative and significant impact on turnover intention variables, but had a positive and significant impact on job satisfaction. Job satisfaction had a negative and significant impact on turnover intention. Moreover, job satisfaction in its influence on organizational commitment variable towards turnover intention only resulted on partially mediate and job satisfaction in its influence on the organizational justice variable towards turnover intention also only resulted in partially mediate.
\end{abstract}

Keywords: Organizational commitment, organizational justice, job satisfaction, turnover intention.

\section{INTRODUCTION}

The banking sector in Indonesia has been massively transformed into the shift in the banking business which focusing on serving companies (corporate banking) to get more eyeing on serving individuals (consumer banking). Therefore, the human resources are seen as an important factor in banking which could determines the success or failure of a company in achieving its goals.

One of issue which facing by human resource now are related to labor in a bank which specifically relates to an employee turnover intention. Turnover intention reflects the 
employee's desire to leave the organization and look for alternative employment elsewhere. As According to the data which authors found on the field at PT. Bank XYZ at Jakarta BSD's Regional Office could be explained if that were percentage cycle of entering and leaving employees in 2016 to 2018 had reached $11 \%$ of percentage. This data showed that every year the number of employees who left and entered was inconsistent and tends to increase or in other word it said that there has an issue with this high turnover intention at PT. Bank XYZ in Jakarta BSD's Regional Office.

With these current issue which occured at PT. Bank XYZ Jakarta BSD's Regional Office, then the author conducted a pre-research to 30 respondents who are employees at PT. Bank XYZ's Regional Office in Jakarta BSD. And from these pre-research results, $70 \%$ of respondents stated that they were not committed to staying at the company, and $60 \%$ of respondents stated that they felt that there was an injustice at work, also $67 \%$ of respondents stated that they were dissatisfied with work in this company and 54\% of respondents wanted to move or leave the company.

Quoted from that phenomenon issue which occured in the research location, its dragged the authors interested in conducting further research with the title "The Role of Organizational Commitment and Organizational Justice in influencing Turnover Intention Through Job Satisfaction as its Mediates variable”.

\section{LITERATURE REVIEW}

\section{Organizational Commitment}

According to Robbins \& Coulter (2016) the organizational commitment is an further extent that employee do to identify with certains organization and its goals in order to retain the membership of that organization. According to Robbins \& Judge (2008:100) in Prasetyo, et al (2021) organizational commitment could be defined as an condition where the employee take sides to the organization and its goals and desired to defend itself as part of membership of the organization. Luthans (2011) stated that there are 3 (three) dimensions of organizational commitment such as: affective commitment, continuously commitment and normative commitment.

\section{Organizational Justice}

According to Robbins \& Judge (2014:144) organizational justice coulf be defined as the whole perception to what is fair in the workplace which consist of distributive justice, procedural justice, informational justice and interpersonal justice. According to Kreitner \& Kinicki (2010:221) organizational justice reflects on the extent to which employees see how they are treated fairly in the workplace. According to Ivancevich, et al (2004:136) the organizational justice is an organizational science research which focuse on perceptions and judgments by employees about the reasonableness of their organization's basic procedures and decisions. Usmani \& Jamal (2013) stated that there are three main dimensions of organizational justice which is a distributive justice, procedural justice and interactional justice. 


\section{Job Satisfaction}

The construction of job satisfaction is broadly defined as an positive emotional state which reflects from an affective response to work situations (Locke, 1976 in Herminingsih, 2017). According to Sunyoto (2013:15) job satisfaction is an pleasant or unpleasant emotional state which employees viewed from their work. Meanwhile, based on Luthans (2008:431) job satisfaction is a characteristic and challenges that arise in the job which could reveal the satisfaction. According to Noe et al (1997:23) in Fajarto, et al (2019) were explained that job satisfaction would create a pleasant feeling in accordance with the perception that someone job has fulfills the value of other person's important work. According to Luthans (2008:431) which divided several factors that could affect the job satisfaction such as the job itself, salary, promotion, supervision, and work groups/coworkers.

\section{Turnover Intention}

Mathis \& Jackson (2011:159) argues that the turnover is a process when an employee leaves an organization and job positions and where that position should be replaced by someone else. Mobley (2011:15) has defines that turnover intention as the tendency or intention from the employees to quit their job voluntarily or move from one workplace to another based on their will. Robbins \& Judge (2008:100) in Prasetyo, et al (2021) has written that the presence of organizational commitment in an employee will shape their attitude based on organization desired and would become part of it. According to Mobley (2011:150) there are three indicators which often used to measure turnover intention, namely: thoughts of quitting, intention to quit and intention to search for another job.

\section{Previous Research}

Research by Luqman, et al (2012) on the public sector in Nigeria stated that the employees would be more committed to provide excellent services to consumers when they are feel satisfied towards their work and given right path for their career advancement. Herminingsih (2017) and Zagladi et al (2015) found that there has an significant and positive impact from organizational justice to job satisfaction. Prasetyo, et al (2021) and Chan \& Ao (2018) who found that organizational commitment has the most dominant direct effect towards turnover intention, therefore the companies need to instill the organizational values on the employees in order to create their own pride and discourage them from exit. Putra (2014) who found that organizational justice had a negative and significant impact on turnover intention at the company. Chan \& Ao (2018) and Zagladi, et al (2015) said that job satisfaction is negatively related to turnover intention. Zagladi, et al (2015) who discovered that artificially the job satisfaction would be able to mediate the influence from organizational justice to turnover intention.

\section{Theoretical Framework and Hypothesis}

According to the background, research purposed, those theoretical studies and previous research which has been mentioned previously, the theoretical framework and hypothesis that could be drawn based on this research are as follows: 


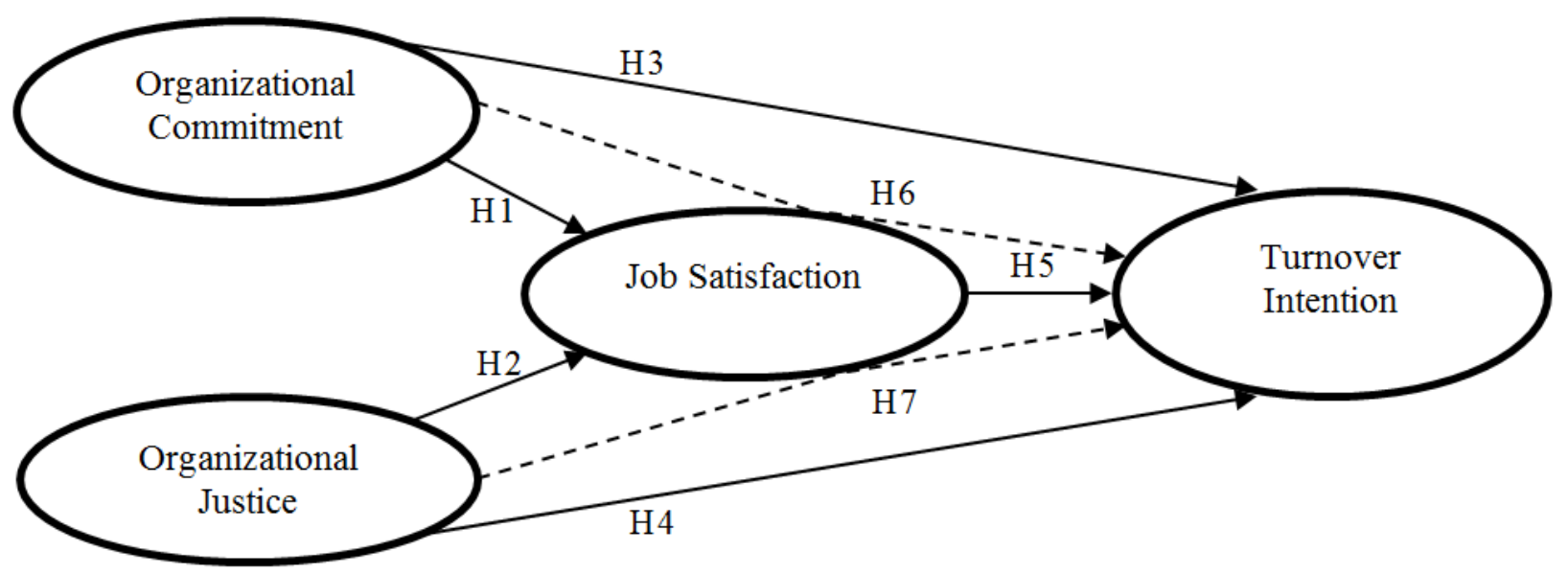

Figure 1. Theoretical Framework

H1: Organizational commitment has a positive and significant impact on job satisfaction. $\mathrm{H} 2$ : Organizational justice has a positive and significant impact on job satisfaction. H3:Organizational commitment has a negative and significant impact on turnover intention.

H4: Organizational justice has a negative and significant impact on turnover intention.

H5: Job satisfaction has a negative and significant impact on turnover intention.

H6: Job satisfaction could acts well in mediating the impact which caused by organizational commitment to turnover intention.

H7: Job satisfaction could acts well in mediating the impact which caused by organizational justice to turnover intention.

\section{RESEARCH METHODS}

This research used an quantitative method by explanatory design and causality. This research has purposed to revealed those influence which caused by an organizational commitment and organizational justice towards turnover intention through job satisfaction. Each variable will be break down into the appropriate dimensions and then reduced to an indicator of the questionnaire questions. The population that used in this research was all employees at PT. Bank XYZ in Regional Office of Jakarta BSD which amounted on 250 employees. According to the calculation of the Slovin formula above, the number of samples that would be the object of the research was 154 respondents. The Selection of respondents would be carried out by proportional stratified random sampling. The Researchers used a quantitative descriptive method based on the research purpose such as hypothesis test to those empirical model which has more than one dependent variable. The researchers used SEMPLS, which is a variant-based Structural Equation Model (SEM) or partial least square (PLS) to analyze the hypothesis.

\section{RESEARCH FINDINGS AND DISCUSSIONS \\ Descriptive Statistical Analysis}

According to the descriptive analysis results which found in this research, it was illustrated that the respondents' perceptions of organizational commitment, organizational justice, and job satisfaction were quite high with a mean value of $3.459,3.601$ and 3.541 . 
Meanwhile, respondents' perceptions on turnover intention were still low with a value of 2.754 .

\section{Outer Model Test}

Based on the convergent validity analysis, the loading factor value from all indicators in organizational commitment, organizational justice, job satisfaction and turnover intention has a range value on 0.733 to 0.941 so it was declared valid (>0.700).

According to the analysis from Cronbach's alpha and composite reliability, the research variables (organizational commitment, organizational justice, job satisfaction, and turnover intention) had a range value on 0.830 to 0.968 so they were all declared reliable $(>0.700)$.

\section{Inner Model Test}

According to the path analysis test results through SmartPLS bootstrapping, the following results that obtained were:

Table 1. Path Coefficient Value and P-Values (Direct and Indirect Effects)

\begin{tabular}{|l|r|r|r|r|r|}
\hline & $\begin{array}{c}\text { Original } \\
\text { Sample (O) }\end{array}$ & $\begin{array}{c}\text { Sample } \\
\text { Mean (M) }\end{array}$ & $\begin{array}{c}\text { Standard } \\
\text { Deviation } \\
\text { (STDEV) }\end{array}$ & $\begin{array}{c}\text { T Statistics } \\
(|\mathrm{O} / \mathrm{STDEV}|)\end{array}$ & $\begin{array}{c}\text { P } \\
\text { Values }\end{array}$ \\
\hline \multicolumn{6}{|c|}{ Direct Effect } \\
\hline $\begin{array}{l}\text { Organizational Commitment > } \\
\text { Job Satisfaction }\end{array}$ & 0.229 & 0.227 & 0.074 & 3.118 & 0.002 \\
\hline $\begin{array}{l}\text { Organizational Justice > Job } \\
\text { Satisfaction }\end{array}$ & 0.694 & 0.699 & 0.058 & 11.932 & 0.000 \\
\hline $\begin{array}{l}\text { Organizational Commitment > } \\
\text { Tumover Intention }\end{array}$ & -0.193 & -0.195 & 0.085 & 2.276 & 0.023 \\
\hline $\begin{array}{l}\text { Organizational Justice > } \\
\text { Tumover Intention }\end{array}$ & -0.364 & -0.367 & 0.141 & 2.579 & 0.010 \\
\hline $\begin{array}{l}\text { Job Satisfaction > Tumover } \\
\text { Intention }\end{array}$ & -0.294 & -0.291 & 0.133 & 2.204 & 0.028 \\
\hline \multicolumn{7}{|c|}{ Indirect Effect } \\
\hline $\begin{array}{l}\text { Organizational Commitment > } \\
\text { Job Satisfaction > Tumover } \\
\text { Intention }\end{array}$ & -0.067 & -0.063 & 0.034 & 1.983 & 0.048 \\
\hline $\begin{array}{l}\text { Organizational Justice > Job } \\
\text { Satisfaction > Turnover } \\
\text { Intention }\end{array}$ & -0.204 & -0.206 & 0.099 & 2.053 & 0.041 \\
\hline
\end{tabular}

The results which appeared in the Table 1 shows that: Organizational commitment and organizational justice have a directly positive and significant impact on job satisfaction; Organizational commitment, organizational justice and job satisfaction have a negative and significant impact on turnover intention. However, the indirect influence occured between organizational commitment and organizational justice towards turnover intention through the role of job satisfaction as an mediate variable which only shows a weak/small effect, so it could be interpreted that job satisfaction could partially mediated. 


\section{$\mathbf{R}^{2}$ Evaluation, GoF, and Predictive Relevance $\left(\mathbf{Q}^{2}\right)$}

$\mathrm{R}^{2}$ value which earned from the job satisfaction variable was 0.761 and $\mathrm{R}^{2}$ value which earned from the turnover intention variable was 0.623 . The $\mathrm{R}^{2}$ value was illustrated that the level of determination from the exogenous variables (organizational commitment and organizational justice) towards the endogenous variables was quite high.

The results of the Goodness of Fit Index (GoF) measurement shows that it has value of 0.751 . Based on these results, it could be concluded that the mixed performance between the measurement model (outer model) and the structural model (inner model) as a whole was quite good because the Goodness of Fit Index (GoF) had value more than 0.10 (small scale).

According to on the results of the predictive relevance $\left(\mathrm{Q}^{2}\right)$ calculation, it shows that had value of 0.9098 or in other words, the value of $Q^{2}>0$, so the exogenous latent variable was suitable as an explanatory variable which is able to predict the endogenous variables, namely job satisfaction and turnover intention or in other words it proved that this model has a good predictive relevance value.

\section{Discussion}

The results from the hypothesis 1 (H1) test were accepted which means that the organizational commitment variable had a positive and significant impact on the job satisfaction variable. These results were relevant to the statements from Handoko (2001), Mathis \& Jackson (2011) which stated if the job satisfaction are the reflects of someone's feelings towards their work, when someone is satisfied with their work they would be more committed to the organization. And its also in line with the research from Boles et al (2007) in several American companies stated that the provision of an appropriate salaries and promotions will affect the employees' desire to remain loyal to the organization.

The Hypothesis $2(\mathrm{H} 2)$ test results were accepted which has the meaning that the organizational justice variable had a positive and significant impact on the job satisfaction variable. The results were relevant to the theory of Kreitner \& Kinicki (2010: 221) which stated if the organizational justice is an reflects of the extent to which employees see how they are treated fairly in the workplace. This was in line with the research by Herminingsih (2017) and Zagladi, et al (2015) who found that there has a positive and significant influence from the organizational justice towards the job satisfaction.

The Hypothesis 3 test results $(\mathrm{H} 3)$ were accepted which means that the organizational commitment variable had a negative and significant impact towards the turnover intention variable. These results were relevant to the statement from Robbins \& Judge (2008: 100) in Prasetyo et al (2021) which stated that through organizational commitment in a person, the employees would shape their attitude whic taking sides on the organization and it goals and become part of the organization. This was also in line with research by Prasetyo et al (2021) and Chan \& Ao (2018) who found that organizational commitment has the most dominant direct effect on turnover intention, therefore the companies needs to instill the organizational values in every employees in order to make them feel proud and discouraged them from leaving the organization. 
The Hypothesis 4 test results (H4) were accepted which means that organizational justice had a negative and significant impact towards the turnover intention. These results were relevant to research which conducted by Suciningtyas (2004) that occured in the furniture industry at the city of Semarang, it was proved that perceived external justice would negatively affect the employees' desire to leave.

The Hypothesis 5 (H5) test results were accepted which means that job satisfaction had a negative and significant impact on turnover intention. These results were relevant to Robbins \& Coulter (2016) who examined that the correlation between job satisfaction and Turnover Intention is stronger. The Satisfied employees would have a lower turnover rate, while dissatisfied employees would have a higher turnover rate. These results were in line with the research conducted by Chan \& Ao (2018) and Zagladi, et al (2015).

According to the research findings which could be seen that the mediate role from the job satisfaction variable on its influence to the organizational commitment variable towards turnover intention only resulted in partial mediation. These results were relevant to the statement from Falkenburg \& Schyns (2007) in Biantoro \& Sihombing (2012) which stated that the higher organizational commitment and job satisfaction then it would reduce the turnover intention.

According to the research results, it could be seen that the mediated act from the job satisfaction variable on its influence to the organizational justice variable towards turnover intention which only resulted in partial mediation. These results were relevant to the results from research which conducted by Al Afari \& Elanain (2014) who concluded that the employees who shows positive perceptions of distributive justice and procedural justice would have a high level of job satisfaction and create low intention to leave.

\section{CONCLUSION AND SUGGESTION Conclusion}

According to the research findings and discussion above, there has several following conclusions that could be written such as:

1) Organizational commitment variable had a negative and significant impact on turnover intention.

2) Organizational justice variable had a negative and significant impact on turnover intention.

3) Organizational commitment variable had a positive and significant impact on job satisfaction.

4) Organizational justice variable had a positive and significant impact on job satisfaction variable.

5) Job satisfaction variables had a negative and significant impact on turnover intention variables.

6) The role of Job satisfaction variable on the influence of Organizational commitment towards turnover intention was partially mediated (partial mediation). 
7) The role of Job satisfaction variable on the influence of Organizational justice towards turnover intention was partially mediated (partial mediation).

\section{Suggestion}

According to the analysis results from the discussion and some of the conclusions which mentioned above, there has several suggestions that could be recommended in order to complement the research results as could be written as follows:

1) As for organizational commitment, the continuous commitment is dimension which has a huge impact towards turnover intention, so it is necessary to have a high commitment so it would improved the employee performance. If it suceed to get down then it would reduce the intensity of exit employees.

2) As for organizational Justice, the interactional justice are the dimensions which have a huge impact towards turnover intention, so it might be necessary to increase fairness from the superiors so it would enhance the employee performance as well.

3) As for job Satisfaction, the co-workers are the dimension which hold the strongest correlation with turnover intention so there has several things that need to be done in an effort to reduce the perceived conflicts so then the turnover intention could be reduced as well. Some things that could be done are: 1) Hold the healthy competition in the company where you work 2) Respecting each others individual rights and 3) Working together as a team in the company where you work.

4) For further research, it is expected that could be investigate further to other mediate variables which might have correlation between organizational commitment and organizational justice towards turnover intention. Besides, those influence from job satisfaction in this research has opens any possibility of other factors which might have any affects on the employee job satisfaction.

5) Further research is needed with adding those respondents who are works in structural positions (at least as Head of Division) to seen the affect occurs from turnover intention on the organizational justice variable.

\section{REFERENCES}

Al Afari, T. S., \& Abu Elanain, H. M. (2014). Procedural and Distributive Justice as Mediators of the Relationship between Interactional Justice and Work Outcomes: An Empirical Study of the UAE Public Health Care Sector. Journal of Applied Business Research, 30(4), 1091-1108. https://doi.org/10.19030/jabr.v30i4.8657

Biantoro, L.C., \& Sihombing, R.P. (2012). Pengaruh Komitmen Organisasi Terhadap Turnover Intention Melalui Kepuasan Kerja Dengan Budaya Organisasi Sebagai Variabel Anteseden. Jurnal Akuntansi Bisnis, XI(21), 61-94.

Boles, J., Madupalli R., Rutherford, B., \& Wood J.A. (2007). The Relationship of Facets of Salesperson Job Satisfaction with Affective Organizational Commitment. Journal of Business and Industrial Marketing, 22(5), 311-321.

Chan, S.H.J., \& Ao, C.T.D. (2018). The Mediating Effects of Job Satisfaction and Organizational Commitment on Turnover Intention, in the Relationships Between Pay 
Satisfaction and Work-Family Conflict of Casino Employees. Journal of Quality Assurance in Hospitality \& Tourism, 1-24. doi:10.1080/1528008x.2018.1512937 .

Fajarto, S.P, Aima, M.H., \& Karsono, B. (2019). The Effect of Compensation and Job Satisfaction on Increasing Productivity of Asuransi Jasindo Head Office Employees Mediated by Motivation Variable. International Journal of Innovative Science and Research Technology, 4(7), 100-113.

Handoko, T.H. (2001). Manajemen Personalia dan Sumber Daya Manusia. Yogyakarta: BPFE Yogyakarta.

Herminingsih, A. (2017). The Influence of the Organizational Justice and Trust to the Leaders on Employee Engagement with Job Satisfaction as Intervening Variable. Archives of Business Research, 5(2), 56-69.

Ivancevich, J.M., Donnely, J.H.Jr., \& Gibson, J.L. (2004). Management: Principles and functions, 4th ed. New Delhi: Richard D. Irwin, Inc.

Kreitner, R., \& Kinicki, A. (2010). Organizational Behavior. New York: McGraw-Hill.

Luthans, F. (2008.) Organizztional Behavior. McGraw-Hill Companies, Inc. New York.

Luthans, F. (2011). Perilaku Organisasi. Yogayakarta: Andi.

Luqman, O.O., Bolaji, S., \& Abuubakar, M.J. (2012). Job Satisfaction and Job Commitment; A study of quantity surveyors in Nigerian Public Service. Journal of Business and Management, 7(5), 179-192.

Mathis, R.L., \& Jackson, J.H. (2011). Manajemen Sumber Daya Manusia, Edisi 9. Jakarta: Salemba Empat.

Mobley, W.H. (2011). Pergantian Karyawan: Sebab, Akibat dan Pengendaliannya. Alih Bahasa: Nurul Imam. PT Pustaka Binaman Pressindo. Jakarta.

Prasetyo, J.H., Ariawan, J., \& Ariyanto, E. (2021). An Excellent Strategy in Reducing Turnover Intention at Permata Keluarga Bekasi Hospital. International journal of Scientific \& Technology Research, 10(01), 162-168.

Putra, W.Y. (2014). Pengaruh Keadilan Organisasi Pada Kepuasan Kerja Dan Turnover Intention Karyawan BPR Di Kabupaten Tabanan. Jurnal Manajemen Udayana, 2(9):2579-2614.

Robbins, S.P., \& Coulter, M. (2016). Manajemen, Jilid 1 Edisi 13, Alih. Bahasa: Bob Sabran Dan Devri Bardani P. Erlangga. Jakarta.

Robbins, S.P., \& Judge, T.A. (2014). Perilaku Organisasi. Jakarta: Salemba Empat.

Suciningtyas, E. (2004). Pengaruh Keadilan Organisasional terhadap Komitmen Organisasional dan Keinginan Karyawan untuk Keluar dari Organisasi. Jurnal Pendidikan Penebur, (1), 3-15.

Sunyoto, D. (2013). Teori, Kuesioner, dan Proses Analisis Data Perilaku Terhadap Kinerja Individual. Universitas Katolik Widya Mandala Madiun.

Usmani, S., \& Jamal, S. (2013). Impact of Distributive Justice, Procedural Justice, Interactional Justice, Temporal Justice, Spatial Justice on Job Satisfaction of Banking Employees. Review Integrative Business and Economics Research, 2(1), 351-383.

Zagladi, A.N., Hadiwidjojo, D., Rahayu, M., \& Nurmijati, N. (2015). The Role of Job Satisfaction and Power Distence In Determining The Influence of Organizational 
Justice Toward The Turnover Intention. Procedia - Social and Behavioural Sciences 211(2015), 42-48. 